\title{
Phytoremediation of Potentially Toxic Element via Absorbtion and Translocation by Naturally Grown Plants Calotropis Procera and Solanum Nigrum from Polluted Agricultural Field Near by Industrial Area, Chinhat Lucknow U.P.(India)
}

\author{
Neeta Pandey, Ram Bharose
}

\begin{abstract}
Phytoremediation is an eco-friendly and has beeen defined as the in situ use of plants to stabilise, remediate, and reduce or restore contaminated soil. Current research was conducted to know the best accumulator plants Forcontaminated agricultural land, of potentially trace elements in soil and plants. Total $\mathrm{Fe}, \mathrm{Cu}, \mathrm{Zn}$ and $\mathrm{Pb}$, have been estimated in soil and plant species of contaminated and control site. Two plants species calotropis procera and solanum nigrum from contaminated and non-contaminated area has been taken. It is revealed that Solanum Nigrum and CalotropisProcera growing in contaminated area can accumulate some of the PTE (Potentially Toxic Elements) like $\mathrm{Fe}, \mathrm{Cu}, \mathrm{Zn}$ and $\mathrm{Pb}$. Surprisingly, naturally grown plants show highly accumulated metals and which can be used as a best accumulator plant species in the heavily contaminated area.We suggest the cultivation of these plants species because it can be used as a best accumulator plant species. This research will show in selection of best plant species for growing in contaminated area.
\end{abstract}

Keywords: Accumulation, Translocation, Toxic Elements Fe, $\mathrm{Cu}, \mathrm{Zn}$ and $\mathrm{Pb}$.

\section{INTRODUCTION}

Plants which are grown on industrial polluted area accumulate potentially toxic elements (PTE) from the soil and to some extent from air. PTE like iron $(\mathrm{Fe})$, zinc $(\mathrm{Zn})$, copper $(\mathrm{Cu})$, and manganese $(\mathrm{Mn})$ are important metals to plants development while lead $(\mathrm{Pb})$, chromium $(\mathrm{Cr})$, nickel (Ni), and cadmium $(\mathrm{Cd})$ are harmful and toxic even at a very low concentration. However, all these metals are harmful and toxic beyond a certain threshold value that may vary with natures and species of trace element and plant. The accumulation of PTE may vary from soil and plant to plant. Epstein and Jefferies (1964) concluded that many varieties of species exhibited different uptake of nutrients in plants. Variation absorption of nutrients in varieties of crops was most likely not caused by a single biological mechanism

Revised Manuscript Received on September 25, 2019

Neeta Pandey, Department of Environmental Sciences Sam Higginbottom University of Agriculture Technology And Sciences, Naini Prayagraj (U.P). Correspondence author: neeta.m12pandey@ gmail.com

Dr. Ram Bharose, Department of Environmental Sciences Sam Higginbottom University of Agriculture Technology And Sciences, Naini Prayagraj (U.P). Correspondence.
(Chang et al., 1982). Metal variation in plants is due to the availability of metals to plants that depend on total concentration in the soil and by the forms in which they occur (Roberts and Johnson, 1978). The availibity of metals in soils to plants is also a function of soil properties like $\mathrm{pH}$, organic carbon, cation exchange capacity (Chaney, 1973; Chambers and Sliddle, 1994; Yassoglouet al., 1987), stage of growth of plants (Xian, 1989) and microorganisms around the root zone. Many metals are retained at surface soil and their concentration will increase at depth (Olaniyaet al., 1991). Fulvic acid and humic acid also play a major role in the migration of metals.

This research shows the behaviour of Solanum Nigrum and Calotropis Procera naturally growing plant species and to understand their capacity of accumulation that we can grow on contaminated soil for prospective utilization of agricultural land.

\section{MATERIAL AND METHODS}

Plant and soil samples were collected during March, 2018 from effluent-contaminated area chinhatIndustrial Belt, containing industrial effluents of automobile industry.located in Lucknow U.P. For each plant sample, 2-5 plant of same species were collected at random. During sampling, morphological status of the plant species and it was taken into consideration based on numbers of leaves, shoot length, root length, color of the leaves, stage of growth, which response to environmental stress condition. This short classification was also adopted by Ray (1990), Barman and Lal (1994). The morphological index different from plant to plant and was classified as normal, healthy, and luxurious.

Soil samples from the surface soil to a depth of $15 \mathrm{~cm}$ around each plant root zone were collected. Soil samples were air dried, ground and passed through a sieve (2 $\mathrm{mm})$. Plant samples were washed with running tap water to clean soil particles adhered to the roots followed by distilled water and then air dried. Background soil and plant samples were similarly obtained from the 
Phytoremediation of Potentially Toxic Element via Absorbtion and Translocation by Naturally Grown Plants Calotropis Procera and Solanum Nigrum from Polluted Agricultural Field Near by industrial Area, Chinhat Lucknow U.P.(India)

uncontaminated site, Chinhat area Lucknow(aerial distance of $\sim 20 \mathrm{~km}$ ). It was chosen as a control site to compare the difference with the contaminated area, its a highway area, were there is air pollution also which may cause a significant increase of $\mathrm{Pb}, \mathrm{Cd}$, and $\mathrm{Zn}$ etc.Plant parts were cut into $2 \mathrm{~cm}$ pieces and dried at $65 \pm 1{ }^{\circ} \mathrm{C}$ for $48 \mathrm{hr}$. Dried samples were powdered and passed through a $2 \mathrm{~mm}$ sieve. Sieved soil and pulverized plant samples were further kept in oven $65 \pm 1{ }^{\circ} \mathrm{C}$ for $24 \mathrm{hr}$. to obtain a accurate weight.

One gram of each plant sample was digested with a mixture (4: $1 \mathrm{~V} / \mathrm{V}) \mathrm{HNO} 3$ and HCIO4 (Buchaure, 1973) overnight. Samples were digested on the hot plate until a clear solution was obtained. It was then filtered andassayed by AAS (Atomic Absorbtion Spectroscopy, LABINDIA AA 7000plus). All analyses were conducted in triplicate.

\section{RESULTS AND DISCUSSION}

To study the accumulation of potentially toxic elements (PTE) in different plant species growing on a mixed industrial effluent -contaminated area at chinhatlucknow; metal levels of $\mathrm{Fe}, \mathrm{Zn}, \mathrm{Cu}, \mathrm{Pb}, \mathrm{Cr}$, and $\mathrm{Cd}$. plants and as well as the soils of contaminated and uncontaminated area were estimated. We have compared the difference in both contaminated site and control site in the metal levels of naturally grown plants. The levels of PTE in the naturally grown plants of the contaminated area were significantly higher than the plants of the control site. Where in plants $\mathrm{Fe}$ and $\mathrm{Cu}$ levels exceeds, and were found higher in the naturally grown plants.

PLANT PART ANALYZED (ROOT)

\begin{tabular}{|c|c|c|c|c|c|c|c|c|}
\hline \multirow{2}{*}{ Plants } & \multicolumn{3}{|c|}{ Contaminated (ppm) } & \multicolumn{4}{c|}{ Control Site (ppm) } \\
\cline { 2 - 9 } & Fe & Cu & Zn & Pb & Fe & Cu & Zn & Pb \\
\hline CalotropisProcera & 112.04 & 3.05 & 0.45 & BDL & 60.68 & BDL & 0.42 & BDL \\
\hline SolanumNigrum & 136.47 & 0.98 & 1.43 & BDL & 63.08 & 0.20 & 0.56 & BDL \\
\hline
\end{tabular}

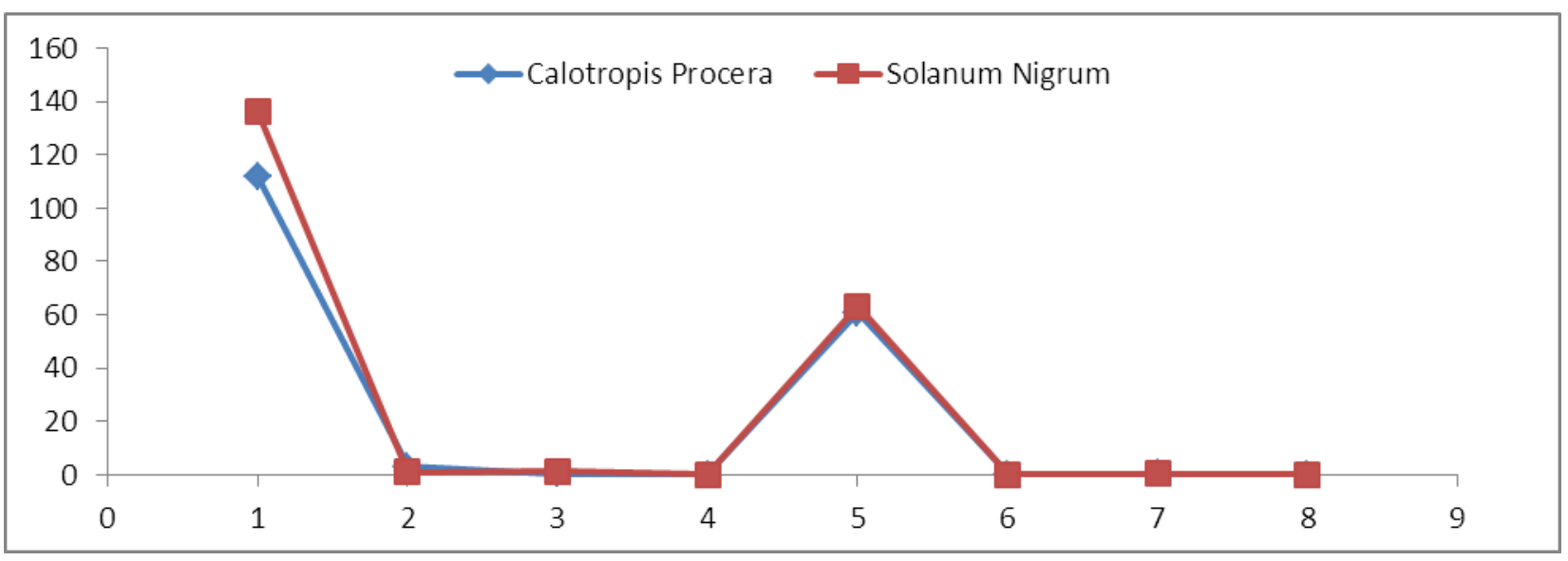

\section{PLANT PART ANALYZED (STEM)}

\begin{tabular}{|c|c|c|c|c|c|c|c|c|}
\hline \multirow{2}{*}{ Plants } & \multicolumn{4}{|c|}{ Contaminated (ppm) } & \multicolumn{4}{c|}{ Control Site (ppm) } \\
\cline { 2 - 10 } & $\mathbf{F e}$ & $\mathbf{C u}$ & $\mathbf{Z n}$ & $\mathbf{P b}$ & $\mathbf{F e}$ & $\mathbf{C u}$ & $\mathbf{Z n}$ & $\mathbf{P b}$ \\
\hline CalotropisProcera & 46.78 & 0.67 & 1.23 & $\mathrm{BDL}$ & 12.19 & 0.47 & 0.39 & $\mathrm{BDL}$ \\
\hline SolanumNigrum & 34.79 & 0.97 & 1.32 & $\mathrm{BDL}$ & 24.80 & 0.43 & 0.01 & $\mathrm{BDL}$ \\
\hline
\end{tabular}




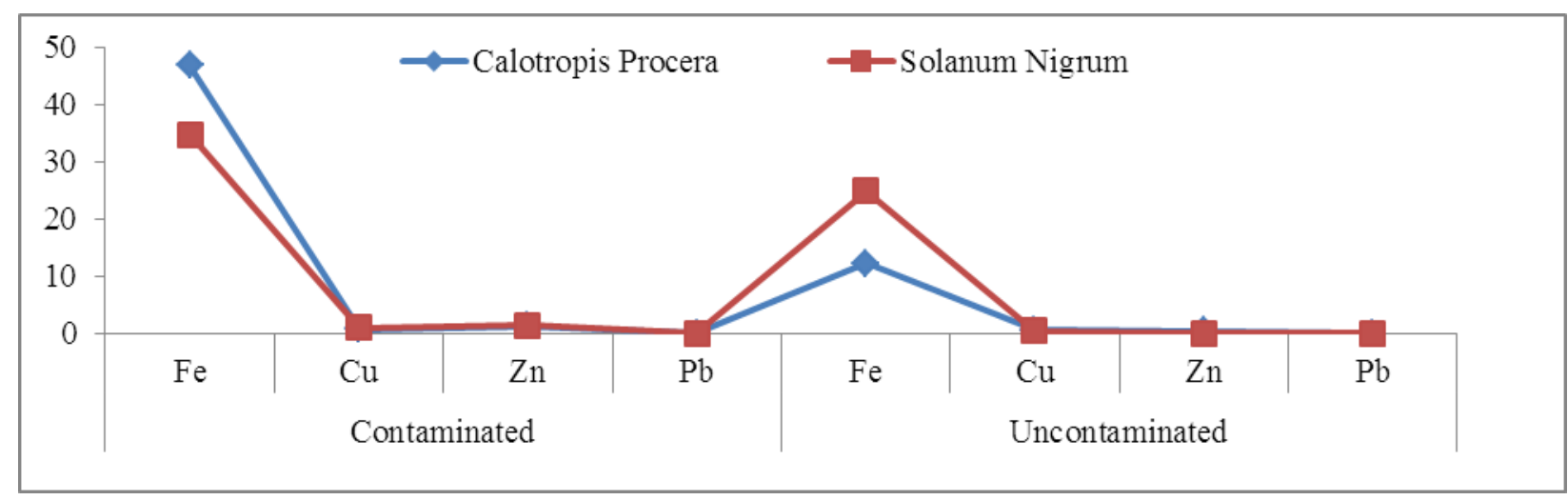

\section{PLANT PART ANALYZED (ROOT)}

\begin{tabular}{|c|c|c|c|c|c|c|c|c|}
\hline \multirow{2}{*}{ Plants } & \multicolumn{4}{|c|}{ Contaminated (ppm) } & \multicolumn{4}{c|}{ Control Site (ppm) } \\
\cline { 2 - 9 } & Fe & Cu & Zn & Pb & Fe & Cu & Zn & Pb \\
\hline CalotropisProcera & 125.48 & 0.52 & 0.02 & 0.57 & BDL & 0.46 & BDL & 0.25 \\
\hline SolanumNigrum & 111.79 & 0.48 & 0.71 & BDL & 36.62 & BDL & 1.42 & BDL \\
\hline
\end{tabular}

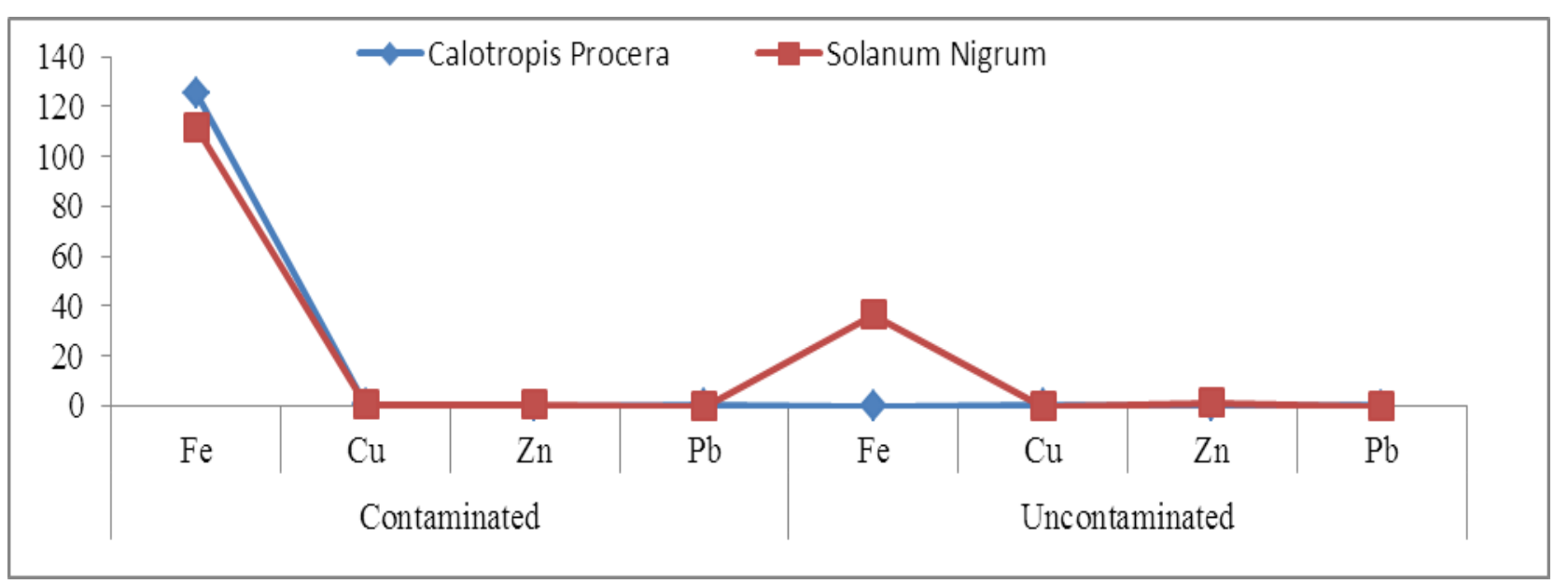

Metals level in Plants were found in the following order:

Leaves: $\mathrm{Fe}>\mathrm{Cu}>\mathrm{Zn}>\mathrm{Pb}$

Stem: $\quad \mathrm{Fe}>\mathrm{Zn}>\mathrm{Cu}>\mathrm{Pb}$

Root: $\mathrm{Fe}>\mathrm{Zn}>\mathrm{Cu}>\mathrm{Pb}$

\section{Distribution of Metal And Its Impact on Plants}

We found that there was higher accumulation of of $\mathrm{Fe}$ in plants ofchinhat area,Gestring and Jarnell (1982), who studied insignificant differences in Fe concentration in plant tissue and soil. There is no uniform distribution of PTE in the root adjacent soils as well as in the different plant species. Soil and plant bioaccumulation relationships are variable from metal to metal and plant to plant. The highest accumulation of $\mathrm{Fe}, \mathrm{Cu}$, and $\mathrm{Zn}$ were found inCalotropisProcera and SolanumNigrum atchinhat area.
The research shows CalotropisProcera and SolanumNigrum are best accumulator plant species for contaminated area and can be grown for phytoremediation. These plants shows higher accumulation to $\mathrm{Fe}, \mathrm{Cu}$ and $\mathrm{Zn}$.

Some plant species may can also differ in their ability to absorb, accumulate, and tolerate PTE.

Visible Phytotoxic Symptoms of Plants

Many laboratory have studied and have demonstrated that many heavy metals, particularly $\mathrm{Cu}, \mathrm{Ni}$, and $\mathrm{Cd}$ can create a series of disorders which can be supplied, and when supplied at concentrations at higher than those normally encountered in the natural conditions. More often than not, these impacts are parallel to reduce the growth rate of the plants which is affected with contaminant effects on an average concentrations. PTE of Chinhat Contaminated Area. Plants don't shows alwaysimpactablesymptoms 


\section{Phytoremediation of Potentially Toxic Element via Absorbtion and Translocation by Naturally Grown Plants Calotropis Procera and Solanum Nigrum from Polluted Agricultural Field Near by industrial Area, Chinhat Lucknow U.P.(India)}

morphologically but sometimay have injurywhich is not visiblebecause of pollutants or because of change in metabolic pathways. These toxic heavy metals are have harmful impact on plants life and there is also reduction in the yield capacity..

(Clijisters and Van Assche, 1985) studied that heavy metals generally cause a decrease in total chlorophyll content.Therefore, alter metabolic pathways of the plant,unhealthy, unluxurious growth, development of vegetables and crops were observed at the contaminated area of chinhatLucknow. The plants gets unhealthy and starts to gets deaf and gets damaged due to pollution whether its air, soil or industrial effluent, were they are not ableto survrive. So, these plants can be grown in industrial contaminated area to accumulate which can be used for phytoremediation.

The higher metalabsorbtion in this soil act as powerful agents of natural selection which may act as higher metal-tolerant plant species in contaminated area. In todays changed environment, plants get adopted through continuous evolution. Thus, some plants species are able to persist in this stressed environment, whereas non-tolerant plant species are quickly eliminated.

In this research, we suggest the cultivation of plantsCalotropisProcera and SolanumNigrum in land irrigated with such mixed industrial effluent.Because these plants will be helpful in accumulating the metals from the contaminated area.

Naturally grown plants grown in the Chinhat location Lucknow shows that the accumulation of the metals when compared to control area, values may likely to constitute a significant chronic health hazard problem to human and cattle when consumed and taken in the long run. Therefore, when its taken dailyand intake of such plants which accumulate more toxic elements should be avoided from consumption. Especially. This is very important in the case of species which is edible particularly leafy vegetables. And, in some cases, naturally grown plants species species may also increase dietary intake of PTE by grazing animals and thereby subsequent trophic levels.

\section{Recommendations to Reduce Pte Load In the Environment}

Some of the techniques can be used and can be adopted for phytoremediation by planting the accumulator plant species:

Metal tolerant species (i.e. hyper accumulator plants species) can be selected and can be alternatively grown with crops and vegetables to eliminate or to reduce some extent of the metal concentration. Organic matter (humus) cab can also be added to the soil which will restrict heavy metal transport to the plants by providing binding sites (ligands). Instead of cultivating in the heavily contaminated land, socialforestry may be taken up as remedial measure to avoid

soil erosion and health hazard in the future. There has been recent interest in the concept of cropping and removing the above ground biomass for decontamination of contaminatedsurface soils. Cultivators should also becouraged to cultivate the accumulator plant species

\section{CONCLUSION}

The information collected is that we can grow these plant species with in the heavily contaminated area for accumulating the metals that would be appropriate for cultivating in land/field irrigated with industrial effluent. Some species of plants which can efficiently restrict the migration of PTE from the contaminated soil. This restriction could be due to the cumulative effect of genetically controlled features, morphological and anatomical differences, or due to the physiology of the ion transport mechanism (Cataldo and Wildung 1978).

\section{ACKNOWLEDGEMENTS}

Authors express their gratitude to Dr. Divya Mishra Prakriti ConsultancyLucknow for providing facilities to carry out this work.

\section{REFERENCES}

1. Anderson,P.J.: 1914, 'The effect of dust from cement mills in the setting of fruit', plant world17, 57.

2. Barman, S.C. and Lal, M.M.: 1994, 'Accumulation of heavy metals (Zn, Cu, $\mathrm{Cd}$, and $\mathrm{Pb}$ ) in soil and cultivated vegetables and weeds grown in industrially polluted fields', Indian J. Environ. Biol.15(2), 107.

3. Buchaure, M.J.: 1973, 'Contamination of soil and vegetation near a Zinc smelter by Zn, Cd, Cu and Pb', Environ. Sci. and Technol. 7(2), 131.

4. Cataldo, D.A. and Widung, R.E.: 1978, 'Soil and plant factors influencing the accumulation of heavy metals by plants', Environ. Hlth. Perspectives 27, 149.

5. Chambers, J.C. and Siddle, R.C.: 1991, 'Fate of heavy metals in abandoned lead zinc tailing ponds: I Vegetation', J. Environ. Qual. 20, 745.

6. Chaney, R.L.: 1973, 'Crop and food chain effects of toxic elements in sludge and effluents: Recycling municipal sludge's and effects on land', U.S. EPA, Washington, D.C., 129-141.

7. Chang, A.C., Page, A.L., Foster, K.W. and Jones, T.E.: 1982, 'Comparison of cadmium and zinc accumulation by four cultivars of barley grown in sludge amended soils', J. Environ. Qual. 11, 409.Clisjsters, H. and Van Assche, F.: 1985, 'Inhibition of photosynthesis by heavy metals', Photosyn. Res.7, 31.

8. Czaja, A.T.: 1962, 'Uber Das Problem Der Zementstaubwirk-Ungen and Pflanzen', Staub 22, 228.

9. Eepstein, E. and Jefferies, R.L.: 1964, 'The genetic basis of selective ion transport in plants', ann. Rev. Plant Physiol. 29, 511.

10. Faucherre, J., Pinart, A.M. and Dutof, A.: 1985, Mecanismebiogeochemique de contamination des vegetaux par le plomb, le cadmium et le zinc C.R. contract C. Comm. Europe, January.

11. Gestring W.D. and Jarnell, W.M.: 1982,'Plant availability of phosphorus and heavy metals in soils amended with chemically treated sewage sludge', J.Environ Qual. 11, 669.

12. Kabata-Pendias, A. and Pendias, H.: 1992, Trace Elements in soil and Plants, $2^{\text {nd }}$ edn., CRC Press, Boca Raton, Fla.

13. Leita, L., Nobili, M.D., Pardini, G., Ferari, F. and Sequi, P.: 1989, 'Anomalous contents of heavy metals in soil and vegetation of mine area in south west Sardinia', Water, Air and Soil Pollut. 48, 423.

14. Mc Nichol, R.D. and Beckett, P.H.T.: 1985, 'Critical tissue concentrations of potentially toxic elements', Plant Soil 85, 107.

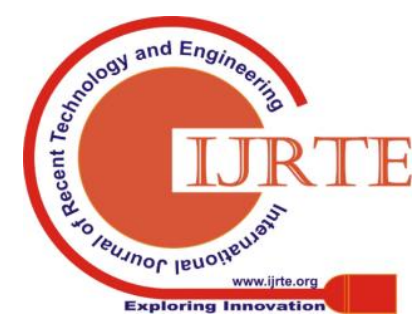


15. Mitchell, R.L., Reith, J. W.S. and Johnston, I.M.: 1957, 'Trace element uptake inrelation to soil content',J.Sci. Food Agri, 8(Suool. Issue), 51.

16. Olaniya, M.S., Bhoyar, R. V. and Bhide, A.D.: 1991, 'Effect of solid waste disposal on land, Indian', J. Environ. Hlth. 34(2), 143.

17. Rao, D.N. and Singh, S.N.: 1978, 'Effect of cement dust pollution on soil properties and on wheat plants', Indian J. Environ.Hlth. 20(3), 258.

18. Ray, M.: 1990, 'Accumulation of heavy metals in plants grown in industrial areas', Indian Biologist, Vol. XXII, No. 2.

19. Roberts, R.D. and Johnson, M.S.: 1978, 'Dispersal of heavy metals from abandoned mine workings and their transference through terrestrial food chains', Environ. Poll. 16, 293.

20. Villanueva, V.R. and Santerre, A.: 1989, 'On the mechanism of adaptive metabolism of healthy-resistant trees from forest polluted areas', Water, Air, and Soil Pollut. 48, 59

21. Xian, X.: 1989, 'Response of kidney bean to concentration andf chemical from of cadmium, Zinc and Lead in polluted soils', Environ. Poll. 57, 127.

22. Yassoglou, N. Kosmas, C. Asimakopoulos, J. and Kallinou, C.: 1987, 'Heavy metal contamination of roadside soils in the greater Athens area', Environ. Poll. 47, 293. 